Н.О. ТКАЧОВА, А.С. ТКАЧОВ

\title{
СИСТЕМА ЦІННІСНИХ ІНДИКАТОРІВ ПОЛІПШЕННЯ ЯКОСТІ ВИЩОЇ ОСВІТИ
}

(C) Ткачова Н.О., 2019

http://orcid.org/0000-0002-1892-9200

(C) Ткачов A.C., 2019

http://orcid.org/0000-0002-4488-1466 http://doi.org/10.34142/2312-2471.2019.61.19

Статтю присвячено визначенню системи ціннісних індикаторів поліпшення якості вищої освіти. Доведено, щуо сьогодні вища освіта $\epsilon$ важливим фактором реформування суспільства, тому визначення науково обгрунтованої системи ціннісних індикаторів поліпшення ї якості є важливою передумовою успішної реалізащї місї освіти. Установлено, щуо окремі аспекти досліджуваної проблеми розкрито в публікаціях І. Беха, О. Вишневського, А. Кірьякової та інших авторів, однак існує потреба в продовженні наукового пошуку в окресленому напрямі. Мета статті - визначити систему иіннісних індикаторів поліпшення якості вищої освіти. Завдання дослідження: розкрити суть поняття «ціннісний індикатор», висвітлити точки зору зарубіжних учених про визначення ціннісних пріоритетів сучасної вищої освіти, проаналізувати позиції вітчизняних украӥнських дослідників щзодо основних показників якості вищуӧ освіти, запропонувати авторську систему иіннісних індикаторів поліпшення якості вищуӧ освіти. У дослідженні використовувався комплекс таких методів: теоретичних (аналіз, зіставлення, узагальнення думок науковців щуодо визначення основних показників (індикаторів) поліпшення якості вищуої освіти); емпіричних (бесіди, анкетування, експертне оцінювання для систематизації висновків фахівців з порушеного питання). На основі аналізу наукової літератури визначено, щчо ціннісні індикатори в системі освіти являють собою певні аксіологічні імперативи, базові цінності, які, $з$ одного боку, детермінуються наявною соиіокультурною ситуацію на конкретному етапі розвитку суспільства, а з іншого боку, - значною мірою визначають подальші тендениії розвитку освіти зокрема та людства загалом. На основі врахування різних точок зору науковців та представленої в раніше опублікованих авторських наукових працях сукупності основних освітніх иінностей зроблено загальний висновок про те, щуо система ціннісних індикаторів поліпшення якості вищзої освіти в Україні має включати такі складники: загальнолюдські цінності, демократичні цінності, академічні цүінності, сімейні изіності й особистісні цүінності. $У$ публікацї також визначено, щуо тільки системне використання зазначених иіннісних індикаторів поліпшення якості вищзӧ освіти дозволить успішно виконати ї̈ місію. 
Ключова слова: система, ціннісний індикатор, якість, вища освіта. загальнолюдські цүінності, демократичні изінності, академічні изінності, сімейні изінності, особистісні изінності.

\section{Tkachova N. O, Tkachov A. S. The System of Value Indicators for the Quality of Higher Education Improvemen}

The article is devoted to defining a system of value indicators for the quality of higher education improvement. It is proved that modern higher education is an important factor in the process of society reformation. So, the definition of a scientifically grounded system of value indicators for its quality improvement is an important prerequisite for successful implementation of the education mission. It is established that some aspects of the issue are revealed in scientific works of I. Bech, O. Vyshnevsky, A. Kiryakova and other scholars. However, there is a need to continue the scientific research in the outlined issue. The purpose of the article is to determine the system of value indicators for the quality of higher education improvement. The research objectives are: to reveal the concept "value indicator" and to highlight the views of foreign scholars on determining the value priorities of modern higher education as well as to offer the author's system of value indicators of the quality of higher education improvement. A set of following methods has been used during the research: the theoretical method (analysis, comparison, generalization of scientists' opinions to determine the main indicators (factors) for the quality of higher education improvement); the empirical method (interviews, questionnaires, expert evaluation) to systematize the experts' conclusions on the issue. Based on the analysis of the scientific works, it has been determined that the value indicators in the education system are certain axiological imperatives and basic values. They, on the one hand, are revealed by the current socio-cultural situation at a particular stage of society, and, on the other hand, they largely determine further trends in education. Based on different points of scientists' view and grounded on previously published author's scientific works concerning to a set of basic educational values, the general conclusion has been made. So, the system of value indicators for the quality of higher education improvement in Ukraine should include the following components: the mankind values, democratic values, academic values, family values and personal values. The publication also states that only the systematic application of these value indicators to improve the quality of higher education will successfully fulfil its mission.

Key words: system, value indicator, quality, higher education, mankind values, democratic values, academic values, family values, personal values.

Постановка проблеми. Сучасний етап розвитку інтенсивно змінного суспільства характеризується глобальними потрясіннями, які негативно впливають на всі сфери життя його членів та поступово взагалі поставили людство на межу виживання. Причому важливо відзначити, що в умовах 
глобалізації навіть незначні відхилення від стабільного стану різних соціальних підсистем нерідко спричиняють колосальні негативні наслідки в масштабах цілої країни, регіону чи навіть світу загалом.

Проте людська спільнота є живою синергетичною системою, на існування й функціонування якої значною мірою впливають не тільки стихійні, хаотичні, випадкові чинники, але й фактор свідомості. Тому в ситуації екологічної, політичної, економічної нестабільності саме цей фактор дає змогу здійснювати на рівні різних соціальних інституцій конкретні цілеспрямовані впливи для забезпечення подальшого збалансованого розвитку людської цивілізації.

Як установлено в дослідженні, величезні можливості щодо забезпечення дієвого впливу на стан різних складників соціоприродної системи й динаміку їх подальшого становлення має система вищої освіти, на яку сьогодні покладаються суттєві надії щодо підготовки компетентних фахівців, здатних давати адекватні відповіді на суперечливі виклики сучасної постінформаційної доби. Своєю чергою це вимагає приділення значної уваги науковців не тільки забезпеченню функціональної підготовленості студентів до виконання в майбутньому своїх професійних обов'язків, але й питанню розкриття та подальшого формування особистісного потенціалу кожної особистості, розвитку їі ціннісної сфери.

Варто також зауважити, що особисті цінності людини є результатом інтеріоризації неї певних суспільних цінностей. У світлі цього актуальною педагогічною проблемою є визначення основних аксіологічних детермінант для оцінювання якості освіти.

Аналіз основних досліджень і публікацій. За результатами проведеного дослідження, окремі аспекти порушеної проблеми знайшли відображення в працях багатьох вітчизняних та зарубіжних науковців. Так, аксіологічні пріоритети освітнього процесу у середній та вищій школі були схарактеризовані в публікаціях I. Беха, О. Вишневського, І. Зязюна, О. Савченко, О. Сухомлинської та ін. Особливості реалізації ціннісного підходу в професійній підготовці майбутніх фахівців у вищій школі розкрито в наукових працях С. Вітвицької, В. Крижка, Г. Огнев’юка, Л. Хомич та ін.

Виділення невирішених раніше частин загальної проблеми. Деякі автори (В. Гончаров, А. Кірьякова, Л. Мосієнко, Т. Ольхова) зробили спробу виокремити деякі аксіологічні індикатори підвищення якості вищої освіти, проте їх відбір не супроводжується чіткою авторською аргументацією, а запропоновані набори цих індикаторів не відрізняються системністю. Тому існує потреба в продовженні наукового пошуку в окресленому напрямі.

Мета та завдання дослідження. Мета статті - на основі аналізу відповідної вітчизняної й зарубіжної наукової літератури визначити систему ціннісних індикаторів поліпшення якості вищої освіти.

Відповідно до мети сформульовано такі завдання наукового пошуку:

1. Розкрити суть поняття «ціннісний індикатор». 
2. Висвітлити точки зору зарубіжних учених про визначення ціннісних пріоритетів сучасної вищої освіти.

3. Проаналізувати позиції вітчизняних українських дослідників щодо основних показників якості вищої освіти.

4. Визначити систему ціннісних індикаторів поліпшення якості вищої освіти в Україні.

Методи дослідження. Для досягнення визначеної мети й завдань наукового пошуку використовувався комплекс таких методів: теоретичних аналіз, зіставлення, узагальнення думок вітчизняних і зарубіжних науковців щодо визначення основних показників (індикаторів) поліпшення якості вітчизняної вищої освіти; емпіричних - бесіди, анкетування, експертне оцінювання аналіз провідних науковців та досвідчених викладачів для систематизації їхніх висновків з порушеного питання.

Виклад основного матеріалу. Визначення сучасних ціннісних індикаторів якості вищої освіти передбачає насамперед розкриття суті самого термін «індикатор». Так, науковці (В. Самуляк, Р. Фещур, С. Шишковський, Н. Яворська) наголошують, що кожний індикатор є показником (свідченням, доказом, ознакою) стану певного об'єкта, проте не кожний показник $є$ його індикатором. Адже індикатором може виступати тільки провідний показник, який дає змогу систематично відстежувати, оцінювати й аналізувати стан цього об'єкта, здійснювати прогнозування, виявляти тенденції його подальшого розвитку (Feshhur, Samulyak, 2010; Feshhur, Shyshkovskyj, Yavorska, 2006).

Значний інтерес викликала також думка В. Гончарова, А. Кірьякової, Л. Мосіенко, Т. Ольхової, відповідно до якої аксіологічні індикатори підвищення якості освіти являють собою ті цінності, на які в майбутньому має орієнтуватися система освіти й які забезпечуватимуть загальну спрямованість навчальної діяльності студентів (а пізніше - їхньої професійної діяльності), визначаючи в такий спосіб специфіку взаємодії майбутнього фахівця 3 навколишнім світом та іншими людьми.

Автори також зазначають, що зазначені індикатори значною мірою впливають на формування в освітньому процесі «предметних» і «суб'єктних» цінностей майбутніх фахівців, а також цінностей їхнього розвитку (Goncharov, 2013; Kyryakova, Mosyenko, Olxovaya, 2011).

У своїй іншій науковій праці А. Кірьякова уточнює, що в системі освітніх цінностей доцільно виділити дві окремі групи:

- аксіологічні індикатори як базові цінності, на які має орієнтуватися система освіти в майбутньому;

- особисті («предметні», «суб’єктні) цінності, що формуються у студентів під час реалізації освітнього процесу (Kyryakova, 2011, 27).

Оскільки вітчизняна вища освіта активно інтегрується в європейський та світовий освітній простір, доцільно проаналізувати висновки зарубіжних фахівців з цього питання. Так, К. Олдс відзначає, що важливе місце серед індикаторів якості вищої освіти займають сучасні академічні цінності. У цьому 
плані викликає інтерес оприлюднений документ «Підтвердження академічних цінностей в інтернаціоналізації вищої освіти», розроблений членами спеціально створеної міжнародної групи експертів.

Зокрема, у документі наголошується, що сьогодні академічні цінності реалізуються в системі вищої освіти на тлі ії подальшої інтернаціоналізації, що $€$ наслідком процесу глобалізації, котра виявляється в економічній, політичній, соціальній, культурній взаємозалежністю між націями.

К. Олдс констатує, що в останні роки з'явилося багато нових форм освітньої інтернаціоналізації, наприклад галузеві кампуси за кордоном, програми дистанційного навчання 3 глобальним охопленням студентів по всьому світу, міжнародні освітні центри й мережі тощо. Автор також підкреслює, що процес інтернаціоналізації вищої освіти сьогодні відбувається в радикально новому, глобалізованому й диференційованому контексті, а це зумовлює необхідність постійного оновлення його цілей, методів та видів діяльності, а також регулярного переосмислення основних цінностей у сфері вищої освіти (Olds, 2012).

Як цілком справедливо наголошує С. М. Мусіль, у сучасному змінному світі невизначеність уже перетворилася на норму. Однак попри динамічні зміни в усіх царинах життедіяльності людини, у тому числі освітній, актуальною потребою сьогодення $\epsilon$ визначення в системі вищої освіти певних універсальних цінностей, які можуть «діяти як Полярна зірка, допомагаючи коледжам та університетам переміщуватися по незнайомій місцевості» (Musil, 2010: 88).

У такому випадку головною метою вищої освіти стає формування у студентів вищої школи не знань чи навіть компетентностей, а здатності «жити мудро і справедливо» у сучасному «розірваному, динамічному, крихкому світі», бути поінформованими й соціально відповідальними, уміти критично мислити (Musil, 2010, 88).

У цьому плані авторка посилається на висновки У. Черчіля щодо місії університетської освіти, які набули сьогодні нового звучання. Так, видатний діяч підкреслював, що ця освіта має бути насамперед спрямована на навчання майбутніх фахівців не професії, а мудрості, формуванню в них не вмінь реалізовувати певні технологічні прийоми й технічні деталі, а характеру (Coote, 1954, 36-37).

У контексті порушеної проблеми дослідження також викликала інтерес «Національна стратегія розвитку вищої освіти до 2030 року» в Ірландії. Як зазначається в цьому документі, сьогодні пріоритетними напрямами в організації освітнього процесу вищої школи є не тільки навчання студентів юнацького віку, але й надання освітніх послуг більш зрілим за віком людям у межах забезпечення їхнього навчання протягом усього життя та підвищення кваліфікації.

При цьому визначено, що ключовими характеристиками, які в першу чергу знадобляться випускникам закладів вищої освіти для працевлаштування 
на ринку праці в майбутньому, $є$ : здатність критично мислити, швидка адаптованість до змін у навколишньому середовищі та креативність.

У вищевказаному документі також наголошується, що саме випускники вищої школи мають стати в майбутньому основними працедавцями, відомими політиками, новаторами в соціальній сфері, провідними бізнесменами, педагогами, громадськими лідерами, а також гідними громадянами й батьками. У світлі цього необхідно забезпечити, щоб заклади вищої освіти перетворились в осередки нових знань, наукових відкриттів, інноваційних мистецтв та технологій, а також у провідні чинники таких позитивних вимірів і змін:

- інтенсивного розвитку кожного студента як особистості, а також суспільства й держави загалом;

- створення, розвитку та трансляції кожному студенту актуальних для сьогодення соціальних, культурних та економічних цінностей;

- забезпечення економічного розвитку держави, а як наслідок індивідуального благополуччя кожної людини, соціальної рівності в суспільстві та виправдання очікувань і сподівань громадян (National Strategy for Higher Education to 2030 Report of the Strategy Group, 2011, 51).

Під час здійснення наукових розвідок у нагоді також стали матеріали засідання спеціальної комісії 3 питань вищої освіти на тему «Пріоритети прогресу: підвищення рівня вищої освіти в Америці», проведеного в 2017 р. у Каліфорнійському університеті Берклі.

Зокрема, під час обговорення актуальних проблем сучасної вищої освіти в США почесний президент благодійного фонду Спенсера М.С. Макферсон зазначив, що в умовах швидких змін у суспільстві відбуваються відповідні значні зрушення в організації та змісту освіти. Однак сьогодні достатньо складно спрогнозувати, як може бути організована вища освіта навіть у недалекому майбутньому. Для прикладу членами комісії було розглянуто чотири сценарії можливих альтернативних ф’ючерсів, а саме що треба робити якщо:

1) значно зростуть масштаби бідності населення, його майнового розшарування, а як наслідок - збільшиться кількість людей, нездатних платити за навчання у вищій школі;

2) активний розвиток «гігантської економіки» спричинить ситуацію, коли працівників будуть брати на роботу за принципом «завдання за завданням», тобто вони будуть отримувати тимчасову роботу за запитом, а не працювати як штатні робітники;

3) завдяки активному розвитку науки й техніки будуть створені принципово нові освітні технологіі, які спричинять докорінні зміни в організації та змісту вищої освіти;

4) відбудуться екологічні катастрофи чи інші природні або техногенні катастрофи, які значною мірою вплинуть на життя більшості американців та взагалі всього населення Земної кулі. 
Як відзначає М. С. Макферсон, змодельовані вище ситуації об'єднує загальна вимога про те, що кожна з них потребує забезпечення якісної освіти, котра дасть людям змогу «краще мислити, вирішувати проблеми, спілкуватися, незважаючи на їхні індивідуальні відмінності, та бути гнучкими у взаємодії 3 мінливим світом» (Priorities for Progress: Advancing Higher Education in America, 2017).

На основі аналізу вітчизняної наукової літератури встановлено, що українські вчені щодо освітніх цінностей висловлюють думки, які значною мірою корелюють з поглядами їхніх зарубіжних колег. Так, В. Андрущенко, Т. Андрущенко й В. Савельєв стверджують, що аксіологічним ядром сучасної вищої освіти є такі традиційні освітні цінності: рівність доступу громадян до якісної освіти; економізація освіти; демократичність управління освітою.

Це передбачає поєднання засобів державного управління й широкого впливу громадськості; університетська автономія; висока соціальна відповідальність закладів вищої освіти (Andrushhenko, Andrushhenko, Savelyev, 2017: 104-106). Крім того, авторами визначено такі аксіологічні пріоритети для вищої освіти: людиноцентризм, толерантність, миролюбство, екологічна безпека, дотримання прав людини, солідарність (Andrushhenko, Andrushhenko, Savelyev, 2017: 446].

О. Андрієнко, В. Андрущенко, Т. Андрущенко, В. Савельєв також наголошують, що вища освіта відіграє надзвичайно важливу роль у поглибленні інтелектуально-духовних, морально-гуманістичних та організаційно-демократичних основ функціонування держави. При цьому необхідною передумовою становлення студентів як громадян 3 інноваційним світоглядом, які здатні успішно розбудовувати демократичну державу, $\epsilon$ формування в них таких життєво важливих якостей: демократичної культури, критичного мислення, толерантності, креативності (Andriyenko, 2010; Andrushhenko, Andrushhenko, Savelyev, 2017).

Для дослідження вагому значущість мали також теоретичні положення Г. Огнев'юка. Відзначаючи визначальну роль освіти на сучасному етапі розвитку суспільства, цей дослідник наголошує, що сьогодні відбувається формування особистості нового покоління - Homo educatus («людини освіченої»). Вона відрізняється від традиційних ідеалів освіченої особистості тим, що уособлює в собі високий рівень інтелектуально-духовного розвитку людської істоти.

Як уточнюе Г. Огнев'юк, формування зазначеної особистості відбувається під впливом різних біологічних та соціальних чинників, проте провідну роль серед них виконують саме фактори інтелектуально-духовного плану. Однак, за висновками вченого, можливість становлення студента як освіченої людини нового покоління значною мірою залежить від іiі власних активних зусиль у цьому напрямі. Зокрема, майбутній фахівець має усвідомлювати соціобіологічну й духовну суть людської істоти як члена суспільства, активно здійснювати процес самопізнання, оволодівати системою 
знань про єдність та цілісність існуючого світу, відпрацьовувати систему власних цінностей як основи для становлення стійкої життєвої позиції, усвідомлювати відповідальність за досягнення світової гармонії.

Отже, на від відміну від роду Homo sapiens («людина розумна»), представники Homo educatus («людина освічена») не тільки володіють свідомістю і самосвідомістю, але й розуміють необхідність гармонізації свого буття та буття світу, а головне - здатні шляхом прояву активних узгоджених зусиль забезпечувати досягнення цієї гармонії в реальності (Ognevyuk, 2010: 7, 8).

Особливий інтерес в дослідженні викликали ідеї А. Кірьякової, Л. Мосіенко, Т. Ольхової, до яких пізніше приєднався і В. Гончаров, відповідно до яких індикаторами покращення якості сучасної вищої освіти є такі:

- академічні цінності (фундаментальність, інноваційність у викладанні й проведенні наукових розвідок, мобільність, відповідальність, інституційна незалежність, колегіальність, професійна компетентність, критичне мислення, наставницькі відносини між викладачами та студентами, міждисциплінарність досліджень, міжнародне співробітництво викладачів тощо);

- цінності особистісного зростання і благополуччя (індивідуальність, адекватність особи середовищу й ситуації, здоров’я, суб'єкт-суб'єктні відносини, корпоративність, конкурентоздатність випускника, безперервність освіти, професійна мобільність тощо);

- цінності громадянського суспільства (демократія, свобода, соціальна справедливість, культурне розмаїття, соціальна відповідальність тощо);

- організаційні цінності (колегіальне прийняття рішень, свобода у проведенні наукових розвідок, стандартизація якості освіти (освітніх програм), статусна ієрархія на основі наукового авторитету, створення матеріальних цінностей i знань, конкурентоспроможність закладів вищої освіти, їх стратегічне партнерство 3 бізнес-структурами) (Goncharov, 2013; Kyryakova, Mosyenko, Olxovaya, 2011; Kyryakova, 2011).

Для уточнення точок зору щодо аксіологічних індикаторів для системи вищої освіти було також створено експертну групу, до складу якої увійшли 67 науковців і компетентних викладачів різних закладів вищої освіти (Харківський національний університет імені В. Н. Каразіна, Харківський національний педагогічний університет імені Г. С. Сковороди, Харківська державна академія фізичної культури).

У процесі застосування різних діагностичних методів (бесіди, анкетування, експертне оцінювання) було з'ясовано, що майже 92 \% опитаних вважають за необхідне забезпечувати у вищій школі цілеспрямоване формування в студентів не тільки ключових та професійної компетентностей, але й системи життєво важливих персональних цінностей, які дозволять кожному 3 них повноцінно самореалізовуватися як особистості, фахівцю та громадянину. 
Обговорення. Підтримуючи загалом позиції зарубіжних та вітчизняних науковців щодо визначення основних показників оцінки якості сучасної вищої освіти, вважаємо за необхідне воднораз додати, що ці показники мають бути представлені як цілісна система, яка комплексно відображають соціально значущі ціннісні пріоритети для всіх сфер життєдіяльності особистості та суспільства загалом, забезпечуючи гармонізацію їхнього спільного буття.

Висновки. На підставі вищевикладених міркувань визначено, що ціннісні індикатори в системі освіти являють собою певні аксіологічні імперативи, базові цінності, які, з одного боку, детермінуються наявною соціокультурною ситуацією на конкретному етапі розвитку суспільства, а 3 іншого боку значною мірою визначають подальші тенденції розвитку освіти зокрема та людства загалом. У світлі цього ці індикатори значною мірою впливають на організацію і зміст вищої освіти, а як наслідок - на процес інтеріоризації студентами загальносуспільних та предметних цінностей.

На основі врахування точок зору різних науковців з окресленого питання, а також представленої в раніше опублікованих нами авторських наукових працях сукупності основних освітніх цінностей (Tkachova, Tkachov, 2013; Tkachova, 2016) зроблено загальний висновок про те, що система ціннісних індикаторів поліпшення якості вищої освіти в Україні має включати такі складники:

- загальнолюдські цінності (людина, життя, добро, здоров’я, істина тощо);

- національні цінності (рідна мова, національна ідея, національні традиції та звичаї, фольклор тощо);

- демократичні цінності (справедливість, рівність, свобода, толерантність, різноманітність тощо);

- академічні цінності (фундаментальність, інноваційність, мобільність, корпоративність, колегіальність, інтернаціоналізація, компетентність, критичність мислення, конкурентоздатність тощо);

- сімейні цінності (любов, вірність, повага, турбота, відповідальність, взаємопідтримка тощо);

- особистісні цінності (індивідуальність, суб'єктність, моральність, самореалізація, інтелектуальна гнучкість, рефлексивність, швидка адаптованість, ініціативність, активність тощо).

Обгрунтовуючи власну точну зору, пояснимо, що загальнолюдські цінності являють собою ті своєрідні точки дотику, які забезпечують взаєморозуміння між людьми як представниками різних націй та культур, допомагають дійти компромісу у вирішенні складних проблем. Національні цінності сприяють успішності процесу етнічної самоідентифікації кожної особистості, збереженню рідної мови, культури та традицій кожного народу.

Демократичні цінності покладено в основу подальшого реформування суспільства в напрямку створення сприятливих умов для кожного його члена, максимального врахування індивідуальних потреб та соціальних очікувань 
людей. Доцільність виокремлення академічних цінностей як окремої групи аксіологічних індикаторів аргументується тим, що сьогодні існує актуальна потреба у формуванні людини нового типу як «людини освіченої», у необхідності здійснення нею неперервної освіти протягом усього життя.

Сімейні цінності складають основу для зміцнення сім’ї як первинного осередку суспільства, створення оптимальних умов для сімейного виховання дітей. Особистісні цінності визначають загальну спрямованість життєвої активності людини, виступаючи необхідною передумовою для можливості успішної самореалізації в різних сферах, проживання нею осмисленого, активного й щасливого життя.

Отже, можна підсумувати, що сьогодні вища освіта стає основним фактором не тільки підготовки кваліфікованих фахівців, але й формування гідних особистостей, які мають забезпечити подальший розвиток людської цивілізації загалом. У світлі цього тільки системне використання зазначених ціннісних індикаторів поліпшення якості вищої освіти дозволить успішно виконати їі місію.

Перспективи подалыших розвідок. У подальших наукових розвідках передбачається конкретизувати шляхи використання вказаних цінностей як індикаторів в освітній царині.

\section{Jimepamypa}

1. Coote C. R. (1954): Sir Winston Churchill : A Self-Portrait. London : Eyre \& Spottiswoode. 304 p.

2. Musil C. M. (2010). Caryn McTighe Musil. Higher education for modern societies - Competences and values [Bergan S., Damian R. (eds)]. Council of Europe Publishing. No. 15. P. 87-100.

3. National Strategy for Higher Education to 2030 Report of the Strategy Group (January, 2011). 130 p. Retrieved from: https://www.education.ie/en/publications/policy-reports/national-strategy-for-highereducation-2030.pdf.

4. Olds K. (2012). Affirming Academic Values in Internationalization of Higher Education: A Call for Action. Retrieved from: https://www.insidehighered.com/blogs/globalhighered/affirming-academic-valuesinternationalization-higher-education-call-action.

5. Priorities for Progress: Advancing Higher Education in America (Commission on the Future of Undergraduate Education) (2017). Retrieved from: https://www.amacad.org/news/priorities-progress-advancing-higher-educationamerica

6. Андрієнко О. В. Особистість у світоглядній системі координат демократичного суспільства. Наука. Релігія. Суспільство. 2010. № 1. С. 6.

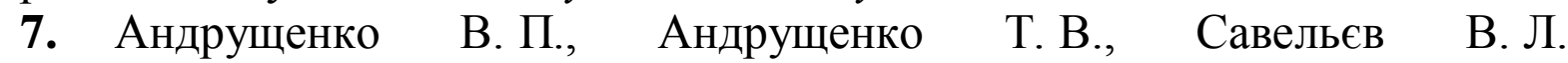
Конституціалізація освітнього простору Європи: аксіологічний вимір. Київ : «МП Леся», 2017. 464 с. 
8. Гончаров В. І. Аксіологічні індикатори підвищення якості освіти та професійних компетенцій сучасного педагога. Гілея: науковий вісник: зб. наук. пр. Київ, 2013. Вип. 70. С. 626-630.

9. Кирьякова А. В. Ценностные ориентиры университетского образования. Вестник Оренбургского государственного университета. 2011. № 2 (121). C. 27-33.

10. Кирьякова А. В., Мосиенко Л. В., Ольховая Т. А. Аксиологические индикаторы качества образования в контексте Болонского процесса. Фундаментальные исследования. 2011. № 8. Ч. 3. С. 519-523.

11. Огнев’юк В. О. На шляху становлення до нового наукового напряму «освітологія». Освітологія - науковий напрям інтегрованого пізнання освіти: матер Всеукр. науково-практ. конф. (Київ, 16 грудня 2010 р.). Київ : Київ. ун-т імені Б. Грінченка, 2010. С. 3-9.

12. Ткачова Н., Ткачова А. Аксіологічні засади організації навчання здібних і обдарованих учнів. Рідна школа. 2013. Вип. 10. С. 14-18.

13. Ткачова Н.О. Теоретичні засади ціннісно орієнтованого шкільного педагогічного процесу як цілісної системи. Системний пiдxid y сучасних педагогічних дослідженнях в Україні : монографія [за ред. С.Я. Харченка]. Старобільськ : ДЗ «Луган. нац. ун-т імені Тараса Шевченка», 2016. С. 119-152.

14. Фещур Р. В., Самуляк В. Ю. Групи показників (індикаторів) оцінювання рівня розвитку підприємств. Вісник Наџіонального університету «Львівська політехніка»: зб. наук. пр. Львів: Вид-во Нац. ун-ту «Львів. політехніка», 2010. № 691. С. 231-239.

15. Фещур Р. В., Шишковський С. В., Яворська Н. Р. Сутність та класифікація індикаторів соціально-економічного розвитку підприємства. Вісник Національного університету «Львівська політехніка»: зб. наук. пр. Львів: Вид-во Нац. ун-ту «Львів. політехніка», 2006. С. 497-500.

\section{References}

1. Coote C. R. (1954): Sir Winston Churchill: A Self-Portrait. London : Eyre \& Spottiswoode. 304 p. (in English).

2. Musil C. M. (2010). Caryn McTighe Musil. Higher education for modern societies - Competences and values [Bergan S., Damian R. (eds)]. Council of Europe Publishing. No. 15. P. 87-100. (in English).

3. National Strategy for Higher Education to 2030 Report of the Strategy Group (January, 2011). 130 p. Retrieved from: https://www.education.ie/en/publications/policy-reports/national-strategy-for-highereducation-2030.pdf. (in English)

4. Olds K. (2012). Affirming Academic Values in Internationalization of Higher Education: A Call for Action. Retrieved from: https://www.insidehighered.com/blogs/globalhighered/affirming-academic-valuesinternationalization-higher-education-call-action. (in English). 
5. Priorities for Progress: Advancing Higher Education in America (Commission on the Future of Undergraduate Education) (2017). Retrieved from: https://www.amacad.org/news/priorities-progress-advancing-higher-educationamerica. (in English).

6. Andriyenko O. V. Osobystist u svitoglyadnij systemi koordynat demokratychnogo suspilstva [Personality in the worldview coordinates of a democratic society]. Nauka. Religiya. Suspilstvo. 2010. No. 1. S. 6. (in Ukranian).

7. Andrushhenko V. P., Andrushhenko T.V., Savelyev V. L. Konstytucializaciya osvitnogo prostoru Yevropy: aksiologichnyj vymir [Structuring of the European educational space: axiological approach]. Kyyiv : «MP Lesya», 2017. 464 s. 4 Retrieved https://shron1.chtyvo.org.ua/Andruschenko_Viktor/Konstytutsializatsiia_osvitnoho_p rostoru_Yevropy_aksiolohichnyi_vymir.pdf?PHPSESSID=c0dc93fd24edd8c9eb5958 75f1albe7e (in Ukranian).

8. Goncharov V. I. Aksiologichni indykatory pidvyshhennya yakosti osvity ta profesijnyx kompetencij suchasnogo pedagoga [Axiological indicators for the quality of education improvement and professional competencies of a modern teacher]. Gileya: naukovyij visnyk: zb. nauk. pr. Kyyiv, 2013. Vyp. 70. S. 626-630. (in Ukranian).

9. Kyryakova A.V. Cennostnie oryentyri unyversytetskogo obrazovanyya [Values of university education]. Vestnyk Orenburgskogo gosudarstvennogo unyversyteta. 2011. No. 2 (121). S. 27-33 (in Russian).

10. Kyryakova A.V., Mosyenko L.V., Olxovaya T.A. Aksyologycheskye yndykatori kachestva obrazovanyya $\mathrm{v}$ kontekste Bolonskogo processa [Axiological indicators of the quality of education in the context of the Bologna process]. Fundamentalnie yssledovanyya. 2011. No. 8. Ch. 3. S. 519-523 (in Russian).

11. Ognevyuk V. O. Na shlyaxu stanovlennya do novogo aukovogo napryamu «osvitologiya» [On the way to foundation of a new scientific approach "educational field"]. Osvitologiya-naukovyj napryam integrovanogo piznannya osvity: mater Vseukr. naukovo-prakt. konf. (Kyyiv, 16 grudnya 2010 r.). Kyyiv : Kyyiv. un-t imeni B. Grinchenka, 2010. S. 3-9. (in Ukranian).

12. Tkachova N., Tkachova A. Aksiologichni zasady organizaciyi navchannya zdibnyx i obdarovanyx uchniv [Axiological principles of gifted and skilled students' education]. Ridna shkola. 2013. Vyp. 10. S.14-18. (in Ukranian)

13. Tkachova N. O. Teoretychni zasady cinnisno oriyentovanogo shkilnogo pedagogichnogo procesu yak cilisnoyi systemy [Theoretical principles of valueoriented school pedagogical process as a holistic system]. Systemnyj pidxid $u$ suchasnyx pedagogichnyx doslidzhennyax v Ukrayini : monografiya [za red. S.Ya. Xarchenka]. Starobilsk : DZ «Lugan. nacz. un-t imeni Tarasa Shevchenka», 2016. S. 119-152. (in Ukranian).

14. Feshhur R.V., Samulyak V.Yu. Grupy pokaznykiv (indykatoriv) ocinyuvannya rivnya rozvytku pidpryyemstv [The groups of indicators (factors) for the level of enterprise development estimation]. Visnyk Nacionalnogo universytetu 
«Lvivska politexnika»: zb. nauk. pr. Lviv: Vyd-vo Nacz. un-tu «Lviv. politexnika», 2010. No. 691. S. 231-239. (in Ukranian).

15. Feshhur R. V., Shyshkovskyj S. V., Yavorska N. R. Sutnist ta klasyfikaciya indykatoriv socialno-ekonomichnogo rozvytku pidpryyemstva [The definition and classification of the indicators for enterprise socio-economic development]. Visnyk Nacionalnogo universytetu «Lvivska politexnika»: zb. nauk. pr. Lviv: Vyd-vo Nacz. un-tu «Lviv. politexnika», 2006. S. 497-500. (in Ukranian). 